\title{
EVIDENCE OF CLOSE RELATEDNESS BETWEEN TURKEY AND BOVINE
}

\section{CORONAVIRUSES}

\author{
Peter Tijssen, Arnold J. Verbeek and Serge Dea \\ CRMC - Institute Armand-Frappier, University of Quebec \\ Laval-des-Rapides, Quebec, Canada, H7N 4 Z3
}

\section{INTRODUCTION}

Immunoelectron microscopy and indirect immunofluorescence studies in 1973 showed that turkey enteric coronavirus (TCV or "Bluecomb agent") is unrelated to another avian coronavirus IBV, and to mammalian coronaviruses (1, 2). Coronaviruses have thus been classified, according to antigenic crossreactivity, into four distinct subgroups within the family, two subgroups of avian viruses and two subgroups of non-avian viruses $(3,4,5)$.

TCV is one of the major causative agents of epidemic diarrhea in turkey poults $(6,7)$. Studies on TCV have long been hampered by the failure to obtain sufficient virus and by the lack of a suitable tissue culture system $(6,8)$. Recently, however, we have been able to adapt this virus to HRT-18 cells, an established human rectal tumor cell line $(9,10)$. Studies on tissue culture- and egg-adapted TCV demonstrated that this virus shares many morphological, biological and molecular properties with bovine coronavirus (BCV; 11, 12), such as (i) the presence of additional short granular surface projections (hemagglutinating glycoprotein), (13, 14); (ii) antigenic relatedness as demonstrated by ELISA, (15); and (iii) intestinal tropism (in respective animals and replication "in vitro" in HRT -18 cells $)(9,16)$.

Here, we report studies undertaken to establish the extent of relatedness between BCV and TCV. These studies led us to conclude that these viruses are very closely related and that they should be reclassified.

\section{RESULTS}

TCV and BCV readily adapted to HRT-18 cells. Although the yield of infective viral particles were comparable for the two viruses, the cytopathic effect of TCV was considerably more pronounced (polykaryocytosis).

Monoclonal antibodies were raised against both TCV (12) and BCV (manuscript in preparation). About 30 MAbs were obtained against the five major structural proteins of each virus. These MAbs were used in Western immunoblotting, neutralisation, and hemagglutination inhibition studies.

The structural polypeptide profiles after electrophoresis under denaturing conditions were comparable for the two viruses. In the presence of 2-mercaptoethanol, the $140 \mathrm{~K}$ polypeptide of TCV was split into two monomers $(65 \mathrm{~K})$, as 


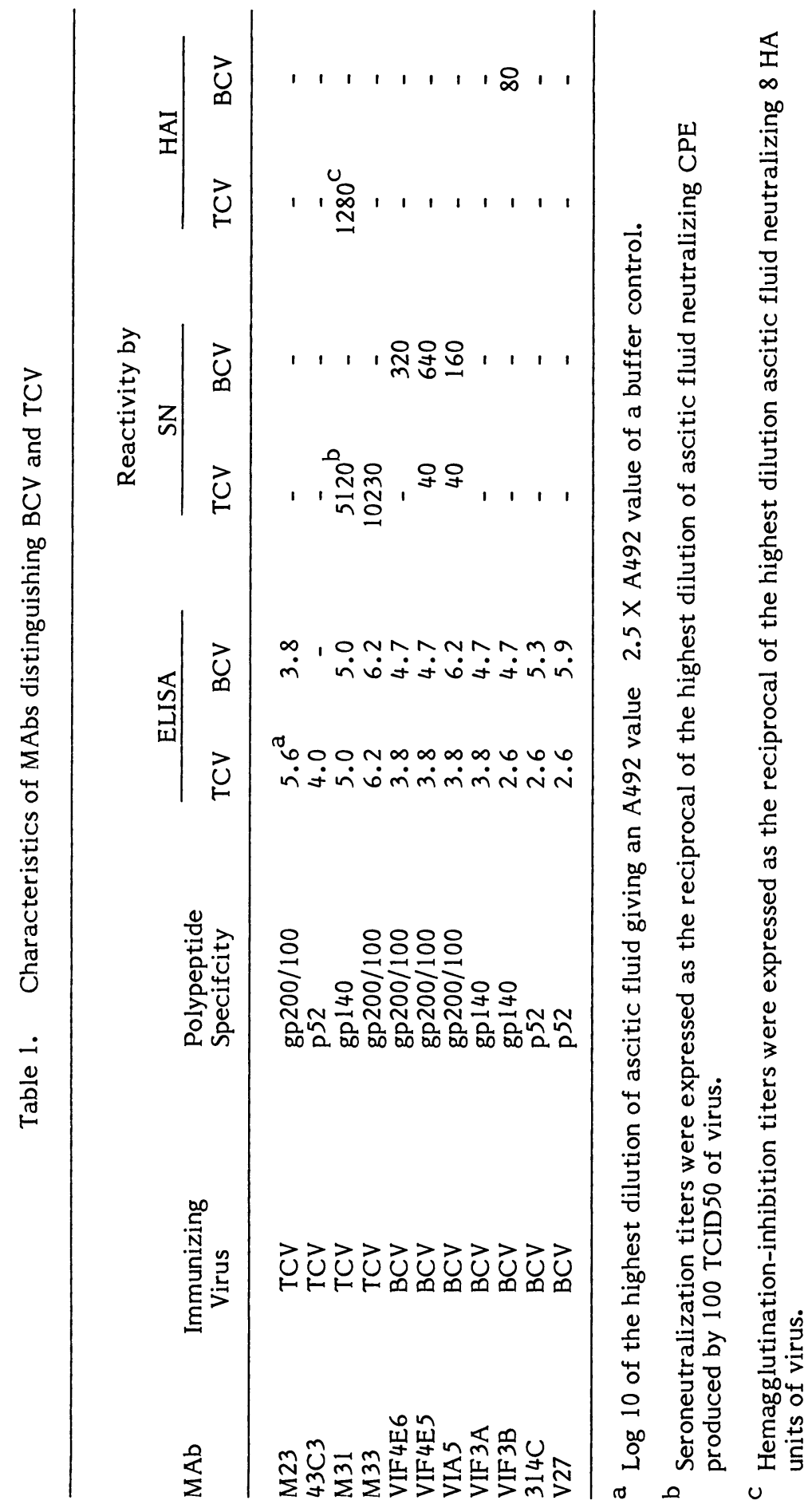


previously described for $\mathrm{BCV}(13,17)$. Western immunoblotting of these proteins was used to establish the protein specificity of 29 anti-TCV MAbs and 20 antiBCV MAbs. Neutralising antibodies were directed to gp 200, gp 120 and gp 100 or gp 140. MAbs inhibiting hemagglutinating activity were all directed to gp 140. The gp 200, gp 120 and gp 100 were shown by MAbs to be interrelated. Polyclonal antisera to TCV and BCV cross-reacted strongly with the proteins of the heterologous virus. Anti-BCV and anti-TCV MAbs revealed also an extensive heterologous activity. Most MAbs reacted similarly against both viruses by ELISA, SN, and HAI tests. At least four anti-TCV and at least seven anti-BCV MAbs could distinguish the two viruses (Table 1). On the other hand, we have shown recently that even among TCV strains, the variation in reactivity exists among the antiTCV MAbs towards their homologous virus (12).

Different radio-isotopically labelled recombinant plasmids, containing both the matrix and the nucleocapsid gene, and other sequences obtained by cloning random-primed CDNA, were independently able to detect TCV under rather stringent hybridization conditions, optimized for BCV detection (17). TCV could also be detected in clinical specimens, using BCV-specific CDNA probes either labeled by nicktranslation or by amplification of BCV specific fragments using the polymerase chain reaction. These data and sequencing studies in progress demons trated the presence of strong homologies between both viral genomes.

Experimental inoculation studies of turkey poults with TCV revealed that egg-adapted and tissue culture-adapted TCV isolates still caused the typical symptoms of enteritis $(9,19)$. Infection of poults with BCV (either from diarrheic fecal samples or from tissue culture strains) did not cause diarrhea, and poults killed after one week p.i. did not show any histologic lesions. However, coronavirus particles were detected by EM and by hybridization with CDNA probes in the clarified intestinal contents from poults from two different groups of seronegative poults.

It can be concluded from these studies that TCV and BCV are, on a molecular basis, almost indistinguishable, although they infect different animal species. Therefore, these viruses should be reclassified into a single subgroup.

\section{ACKNOWLEDGMENTS}

We would like to thank Drs P. Talbot and J.P. Descoteaux (Institut ArmandFrappier), and Dr. A., Bouffard (Animal Disease Research Center, Agriculture Canada, Nepean, Ontario, Canada) for providing rabbit anti-HCV 229E and antiRECV (rabbit coronavirus) hyperimmune sera, and pig anti-HEV sera.

This report was taken in part from a dissertation submitted by S. Dea to the Department of Virology, Institute Armand-Frappier, University of Quebec, in partial fulfillment of the requirements for the Ph.D. degree.

This research was supported in part by grants from the Quebec Federation of Poultry Producers (VOLBEC) and the Conseil des Recherches et Services Agricoles du Quebec. S. Dea has received a Fellowship from the Medical Research Council of Canada.

\section{REFERENCES}

1. K.A. Pomeroy, B.L. Patel, C.T. Larsen, and B. S. Pomeroy. Combined immunofluorescence and transmission electron microscopic studies of sequential intestinal samples from turkey embryos and poults infected with turkey enteritis coronavirus. Am. J. Vet. Res. 39:1348 (1978).

2. A.E. Ritchie, D.R. Deshmukh, C.T. Larsen, and B.S. Pomeroy. Electron microscopy of coronavirus-like particles characteristic of turkey bluecomb disease. Avian Dis. 17:546 (1973). 
3. N.C. Pedersen, I. Wark and W.L. Mengeling. Antigenic relationships of the feline infectious peritonitis virus to coronaviruses of other species. Arch. Virol. 58:45 (1978).

4. M.C. Horzinek, H. Lutz, and N.C. Pedersen. Antigenic relationships among homologous structural polypeptides of porcine, feline and canine coronaviruses. Infect. Immun. 37:1148 (1982).

5. S. Siddell, H. Wege and V. Ter Meulen. The biology of coronaviruses. J. Gen. Virol. 64:761 (1983).

6. B.S. Pomeroy. Coronaviral enteritis of turkeys, In M.S. Holstad, H.J. Barnes, B.W. Calnek, W.M. Reid, and H.W. Yoder (eds), "Diseases of poultry", 8th ed. Iowa's State Univ. Press, Ames (1984).

7. S. Dea and P. Tijssen. Viral agents associated with outbreaks of diarrhea in turkey flocks in Quebec. Can. J. Vet. Res. 52:53 (1988).

8. D.R. Deshmukh, C.T. Larsen, and B.S. Pomeroy. Survival of bluecomb agent in embryonating turkey eggs and cell cultures. Am. J. Vet. Res. 34:673 (1973).

9. S. Dea and P. Tijssen. Isolation and trypsin-enhanced propagation of turkey enteric (bluecomb) coronaviruses in a continuous human rectal tumor (HRT18) cell line. Am. J. Vet. Rec. (in press)

10. W.A.F. Tompkins, A.W. Watrach, J.D. Schmale, R.M. Schultz, and J.A. Harris. Cultural and antigenic properties of newly established cell strains derived from adenocarcinomas of the human colon and rectum. ‥ Natl. Cancer Inst. 52:101 (1974).

11. S. Dea and P. Tijssen. Identification of the structural proteins of turkey enteric coronavirus. Arch. Virol. 99:173 (1988).

12. S. Dea and P. Tijssen. Antigenic and polypeptide structure of turkey enteric coronaviruses as defined by monoclonal antibodies. J. Gen. Virol. (in press).

13. B. King, B.J. Potts, and D.A. Brian. Bovine coronavirus hemagglutinin protein. Virus Res. 2:53: (1985).

14. B.G. Hogue, B. King, and D.A. Brian. Antigenic relationships among proteins of bovine coronavirus, human respiratory coronavirus $\mathrm{OC} 43$, and mouse hepatitis coronavirus A59. J. Virol. 51:384 (1984).

15. J. Laporte and P. Bobulesco. Polypeptide structure of bovine enteric coronavirus: comparison between a wild strain purified from feces and a HRT-18 cell-adapted strain. Adv. Exp. Med. Biol. 142:171 (1981).

16. W. Lapps, B.G. Hogue, and D.A. Brian. Sequence analysis of the bovine coronavirus nucleocapsid and matrix protein genes. Virology 157:47 (1987).

17. A. Verbeek, and P. Tijssen. Biotinylated and radioactive cDNA probes in the detection by hybridization of bovine enteric coronavirus. Molecular Probes 2:209 (1988).

18. N.R. Adams, R.A. Ball, and M.S. Hofstad. Intestinal lesions in transmissible enteritis of turkeys. Avian Dis. 14:392 (1970). 